\title{
"...questo Bassista è buona persona..." \\ A Short Overview of Sources for the Rudolfine Imperial Court Environment's Studies
}

\author{
Michaela Žáčková Rossi / mzackov@gmail.com \\ Ústav hudební vědy, Filozofická fakulta, Univerzita Karlova, Praha, CZ \\ Nadace pro dějiny kultury ve střední Evropě, Praha, CZ
}

\begin{abstract}
The paper presents an overview of non-musical sources in Vienna archives, which can significantly contribute to enlarge our knowledge about the life of musicians under the Emperor Rudolf's II reign. The aulic accounting ledgers register various items of musicians' payments, clarifying different aspects of the Imperial musical environment. Besides the accounting ledgers, other important typologies of documents in Vienna Archives can be studied, as "Panis Briefe", numerous applications for coat-of-arms grants, testaments and repeated requests of the remaining wage payments many years after the servant's activity conclusion etc. These sources are rich in terms of biographical data and sometime contain rare autograph notes of many musicians.

The author focuses her research on the study of Habsburg accounting ledgers under the Emperor Rudolf II (1576-1612) and related Rudolfine non-musical sources. After having reconstructed the Imperial Chapel and all the musical staff on the basis of the regular wage payments, other important documents conserved in Austrian and Czech archives are processing.
\end{abstract}

\section{Key words}

Rudolf II., court, musicians, accounting ledgers, sources 


\section{Introduction}

Historians by over the past few decades have paid attention to the Rudolfine art, culture and scholarship. Many monographs about art at Rudolf II's court have been published, as have been printed volumes devoted to individual aspects and personages of the Rudolfine epoch. Since the late 1980s, also the Rudolfine music has been explored more systematically and on a greater international scale.

Since 2006 the author of this study has focused on an extensive research of the Imperial accounting ledgers regarding the period of the Rudolf II's reign 1576-1612, the so called Hofzahlamtsbücher, which are a very important source not only for musicologists, but for all historians interested in early modern culture and the Rudolfine environment. ${ }^{1}$

After having reconstructed on the basis of the regular wages (Hofbesoldung) the presence of over 300 Imperial musical servants, ${ }^{2}$ remaining categories of payments contained in the Imperial accounting ledgers are now processed. ${ }^{3}$ At the same time other important sources conserved in the Austrian State Archives are examined. ${ }^{4}$ This study presents only some of them, many others have still to be seen in the third step of the author's research.

\section{A. 1 Sources in Austrian State Archives, Finanz- und Hofkammerarchiv: Imperial accounting ledgers}

The Imperial accounting ledgers (Hofzahlamtsbücher) ${ }^{5}$ are conserved in Austrian State Archives in Vienna, the department of Finanz- und Hofkammerarchiv, with the exception

1 PÁNEK, Jaroslav. Knihy habsburské Dvorské pokladny (Hofzahlamtsbücher) jako pramen k dějinám předbělohorského českého státu. In Pocta prof. JUDr. Karlu Malému, DrSc. $k$ 65. narozeninám. Ladislav Soukup (ed.). Praha: Karolinum, 1995, p. 173-181; HENGERER, Mark. Die Abrechnungsbücher des Hofzahlmeisters (1542-1714) und die Zahlamtsbücher (1542-1825) im Wiener Hofkammerarchiv. In Quellenkunde der Habsburgermonarchie (16.-18. Jahrhundert). Ein exemplarisches Handbuch. Josef Pauser - Martin Scheutz - Thomas Winkelbauer (eds.). Wien - München: R. Oldenbourg Verlag, 2004, p. 128-143.

2 The author of this paper conducted a research project commissioned by the Association for Central European Cultural Studies in Prague and granted by the Czech Scientific Foundation GAČR (Projects Nr. 408/06/0449 and P409/10/1028) - first results of this extensive research were anticipated in 2012 (ŽÁČKOVÁ ROSSI, Michaela. The Musicians at the Court of Rudolf II (1576-1612). Die Tonkunst, 2012, Nr. 3, p. 330-339) and a first volume of the monograph The Musicians at the Court of Rudolph II. The Musical Entourage of Rudolph II (1576-1612) reconstructed from the Imperial Accounting Ledgers (Prague, Association for Central European Cultural Studies \& KLP, in press) dedicated to the musical staff and the musicians' regular wages, was announced.

3 The present paper is a result of the second step of the research, granted by the Charles University (GAUK - Project Nr. 1288213), when remaining categories of court payments were studied; this paper anticipate a second volume of the monograph, devoted to clothing and New Year bonuses together with all occasional musicians' payment documented in the Rudolfine accounting ledgers.

4 The author thanks the Direction of Austrian State Archives in Vienna, the department of Finanz- und Hofkammerarchiv [Aulic Chamber Archive] and in particular Dr. Herbert Hutterer, for their generous collaboration in this extensive project.

5 Each Imperial accounting volume is signed as „HZAB + year“. 
of three non-extant volumes from the years 1578, 1579 and 1580. Each ledger (Hofzahlamtsbuch) is divided into two main accounting sections: incomes (Empfang) and expenses (Ausgab). The largest and the most important part of the expenditures are regular wages (Hofbesoldung), the main source to know who, when and in what function was active at the court. In the Hofbesoldung category are included also regular contributions for young trumpet apprentices' maintaining (Trometter Lehrjungen Unterhaltung). ${ }^{6}$

There are, however, many other kinds of expenditures in the Imperial accounting volumes. Some of them were regular (clothing money Claidergeld and New Year bonuses Neujahrgeld), some of them were selected, as regular wage supplements Zupuessgeld, pensions, short-term bonuses or life annuities, other were occasional contributions to marriage or child's baptism, journey-money, exceptional payments and various remunerations.

The Clothing money (Claidergeld) was a fix amount, paid without exception to each servant. The members of the Imperial Chapel (Capellnparthey) received yearly 20 Rhenish guilders for their clothing, while trumpeters and drummers in the Stallparthey had a contribution of 16 guilders. ${ }^{7}$ The regular character of clothing money items complement the Hofbesoldung payments with valuable missing information and eventually correct some minor inaccuracies in the records as it became evident that even in the precisely managed Habsburg administration documents minor omissions of scribes did appear.

Another fix payment reserved to each member of the musical personnel was the New Year bonus (Neujahrgeld). It is quite curious to observe how big is the difference between the amount paid to the Capelnparthey and those reserved for the Stallparthey: while chaplains and singers were granted for Neujahrgeld by approximately a month salary bonus (ca. 15-22 Rhenish guilders), for the trumpeters was reserved as New Year money only a tenth of their monthly remuneration, 1 guilder and 30 kreuzer (sometime registered as 1 Crown). ${ }^{8}$

The fact that the New Year bonuses were not consistently paid out in the same years as regular wages, but often considerably later and en masse for several years back, allows modern researchers to partially reconstruct pertinent information for 1578-1580, years where the items of regular wages are not extant. This category of payments is therefore significant for our knowledge of the otherwise less documented period at the end of the 1570 s in regards to those persons who entered their service at the court in those years for which the books are not extant. For instance, Gregorio Turini's widow received in 1598, more than one year after the musician's death, payments of seventeen New Year bonuses, and it is so far the only evidence that Turini came to the Rudolf's court probably in $1579 .{ }^{9}$

6 ŽÁČKOVÁ ROSSI, op. cit., p. 332 and 335.

7 Rhenish guilder signed in the ledgers as $f l$. (guilder is also called florin).

81 Rhenish guilder $=60$ kreuzer, while 1 Crown $=90$ kreuzer $(=1 \mathrm{fl} .30 \mathrm{kr}$. $)$.

9 Ósterreichisches Staatsarchiv, Finanz- und Hofkammerarchiv [Austrian State Archives, Vienna, Aulic Chamber Archive department] (hereafter ÖstA - HKA), HZAB 1598, f. 362r. 


\begin{tabular}{|c|c|c|c|}
\hline \multicolumn{4}{|c|}{$\begin{array}{c}\text { Typology of expenditures to the musical personnel } \\
\text { in Imperial accounting ledgers } \\
(1576-1612)\end{array}$} \\
\hline \multirow{4}{*}{ U } & \multirow{3}{*}{$\begin{array}{l}\text { Regular payments } \\
\text { to all servants }\end{array}$} & $\begin{array}{c}\text { Hofbesoldung } \\
\text { (included Trometter Lehrjungen } \\
\text { Unterhaltung) } \\
\text { Regular personnel wages }\end{array}$ & $\begin{array}{c}\text { Regular, } \\
\text { paid to all servants }\end{array}$ \\
\hline & & $\begin{array}{c}\text { Claidergeld } \\
\text { Clothing money }\end{array}$ & $\begin{array}{c}\text { Regular, } \\
\text { paid to all servants }\end{array}$ \\
\hline & & $\begin{array}{c}\text { Neujahrgeld } \\
\text { New Year bonuses }\end{array}$ & $\begin{array}{c}\text { Regular, } \\
\text { paid to all servants }\end{array}$ \\
\hline & \multirow{3}{*}{$\begin{array}{l}\text { Regular payments } \\
\text { to selected servants }\end{array}$} & $\begin{array}{l}\text { Zupuessgeld } \\
\text { Regular wages supplements }\end{array}$ & $\begin{array}{l}\text { Regular, } \\
\text { but paid only to selected } \\
\text { servants } \\
\end{array}$ \\
\hline$s$ & & $\begin{array}{l}\text { Pension } \\
\text { Pensions }\end{array}$ & $\begin{array}{c}\text { Regular, } \\
\text { but paid only to selected } \\
\text { servants } \\
\end{array}$ \\
\hline$A$ & & $\begin{array}{c}\text { Provision } \\
\text { Short-term bonuses or life annuities }\end{array}$ & $\begin{array}{l}\text { Regular, } \\
\text { but paid only to selected } \\
\text { servants or heirs }\end{array}$ \\
\hline \multirow[t]{4}{*}{ B } & \multirow{4}{*}{$\begin{array}{l}\text { Occasional payments } \\
\text { to selected servants }\end{array}$} & $\begin{array}{c}\text { Verehrung } \\
\text { Occasional contributions to marriage } \\
\text { or child's baptism }\end{array}$ & $\begin{array}{l}\text { Occasional, } \\
\text { paid only to selected servants }\end{array}$ \\
\hline & & $\begin{array}{c}\text { Zehrung } \\
\text { Journey money }\end{array}$ & $\begin{array}{c}\text { Occasional, } \\
\text { paid only to selected servants }\end{array}$ \\
\hline & & $\begin{array}{c}\text { Extra-Ordinari } \\
\text { Exceptional payments }\end{array}$ & $\begin{array}{c}\text { Occasional, } \\
\text { paid only to selected servants }\end{array}$ \\
\hline & & $\begin{array}{l}\text { Gnadengeld } \\
\text { Various remunerations }\end{array}$ & $\begin{array}{l}\text { Occasional, } \\
\text { paid only to selected servants }\end{array}$ \\
\hline
\end{tabular}

Tab. 1. Typology of payments to the musicians in Imperial accounting ledgers (1576-1612)

Numerous interesting information on the importance or social conditions of individual Imperial servants can be found in sections of regular payments which were designated only to a small part of the personnel, to servants with a particular employment, who were busy in other extra functions or had officially requested a sustainment to the Emperor.

One of these regular, but strictly selected payments, were the wage supplements $(\mathbf{Z u}$ puessgeld), registered initially, in 1576 and 1577, in the same category together with pensions to the servants. ${ }^{10}$ In fact, the Zupuessgeld was a fix supplement to the regular wage, requested by servants themselves with an official letter and approved (or not) by the Emperor. During the reign of Rudolf II these supplements significantly increased, more in the Stallparthey, less in the Imperial Chapel. While in the 1580' the chief trumpeter Francisco Rizzo received as supplement to his regular salary of 18 Rhenish guilders, still 4 guilders and 10 kreuzer, ${ }^{11}$ in the last years of the Rudolfine period the chief trumpet-

10 „Summa aller hiervorbeschriebenen bezalten Pensionen und Zuepueßgeldt [...]“, ÖstA - HKA, HZAB 1576; „Summa der Ausgaben [...] von Irer Khay: Mt: habenden Pension oder Zuepueßgelt [...]“, ÔstA - HKA, HZAB 1577.

11 Rizzo's father, Juan Peter, who was until his death, in 1573, the chief trumpeter of Maximilian II (1564-1576), received monthly Zupuessgeld bonus of 5 Rhenish guilders and 30 kreuzer (= total 66 Rhenish guilders each year). 
ers Lucas Zigotta and then Georg Zigotta were granted each month, besides their salary, by 12 Rhenish guilders. This let us suppose an increasing employment of the chief trumpeters. ${ }^{12}$ Such a supposition can be confirmed by an exceptional, second monthly supplement to Lucas Zigotta, called also Underhaltung (sustainment),$^{13}$ to underline the social character of these payments. ${ }^{14}$

Among the other musicians who obtained the wage supplements are trumpet players Stefano Cadenaro, Cesare Bendinelli and Dominico Gentili, chamber musicians Carlo and Giovanni Paolo Ardesi, violinist Mauro Sinibaldi, organists Paul van Winde, Carl Luython and Jacob Hassler, singers Gerhardt Martin, Lambertus Vreuen, Giovanni Battista Pinello, Bonaventura Le Febure, Georg Furtter and Peter di Nasera.

\section{Pension}

The pension was another kind of wage supplement or sustainment and, as we have seen, often was considered close to the Zuepueßgeld expenses. For instance, the court tenor Giovanni Battista Pinello is documented in 1586 under the Pension and service money (Dienstgelt) category with a sustainment valid until he would take care of the choirboys. ${ }^{15}$ Another example is the Stipendi geldt for 4 years (starting from 1605), to the choirboy Hanns Wenzel Althaus, to let him continue his studies. ${ }^{16}$

The pension, intended as money paid to the old servants after they have concluded their service, was included often under the Provisions. ${ }^{17}$

\section{Provision (short-term payments)}

The Imperial accounting ledgers register various items of sustainment when the musicians became old, after a long service at the Emperor's or, generally, at the Habsburgs' court. Provisions were allowed for the rest of the servant's life ${ }^{18}$ or only for a limited period, for one or more years. ${ }^{19}$ Sometime a short-term payments was designated to the servant's widow. The provision was assigned during their chief trumpeter's activity to Francisco Rizzo, Lucas and Georg Zigotta. Quite exceptional is the provision to the trumpeter Leonso Cappa, promised by the Emperor in 1587 for the musician's

12 The Zupuessgeld record in the volume of 1601 mentions that Lucas Zigotta has been teaching since many years young trumpet apprentices, ÖstA - HKA, HZAB 1601, f. 119v-120r.

13 Starting from 1602 Lucas Zigotta was granted by a second monthly supplement of 4 guilders and 10 kreuzer (in addition to the first one of 12 guilders and to his salary of 18 guilders) for holding in his house musical instruments and books, ÔstA - HKA, HZAB 1602, f. 117v-118r.

14 Also the payment to the tenorist Giovanni Battista Pinello, ÔstA - HKA, HZAB 1585, f. 98v, was defined as Underhaltung.

15 ÖstA - HKA, HZAB 1586, Pension, f. 73v: „[...] seiner Unterhaltung oder Zuepueßgelts in die Kai: Mat: solang Er deroselben Cappelmsinger Khnaben in seiner unterweisung hat [...]“.

16 ÖstA - HKA, HZAB Pension, 1605, f. 76; 1606, f. 74r-v; 1607, f. 88r-v; 1608, f. 59r; 1609, f. 51r - the money was paid to the boy's father, Hanns Althaus.

17 E.g. The pension to the trumpeter Leonso Cappa (and after to his widow), ÓstA - HKA, HZAB 1587, Provision, f. 52v.

18 „Provisionen auf Lebenlang”.

19 „Provisionen auf ain Anzaal Jahr”. 
long and diligent service: it was valid not only until Cappa's death but also his widow Catharina Cappin could profit of it for the rest of her life..$^{20}$ More common were definitely provisions to widows only for two or three years, anyway they could be sometime renewed. ${ }^{21}$

\section{Verehrung}

Imperial servants received occasionally contributions to their marriage or child's baptism. These bonuses corresponded mostly to one or two months salaries, but sometime the cash contribution was replaced by a gift. Our better knowledge and precise definition of the year of birth of Imperial trumpeters' or singer's children, compared with the sustainment money (Unterhaltung) of the young trumpeter apprentices and Singerknaben, can help us to understand better the musical practice regarding their education.

\section{Zehrung}

There are only few payments to the musicians among the journey reimbursements (Zehrung). The first one is to the excellent Italian trumpet and cornetto player (Zinckenblaser) Francesco Mosto, member of a branched lineage of trumpet players working in Habsburg services, who - together with the bass singer Christoph Porro and the chaplain and alto singer Evangelista Vacino - is mentioned in 1591 in a high exceptional payment of 840 guilders. At the end of 1590 these three musicians came to Prague from Graz, as local court Chapel was disbanded after the death of Charles II, Archduke of Austria. ${ }^{22}$

Other reimbursements were recorded in $1602^{23}$ and in $1609^{24}$ for journeys of the high appreciated composer and Imperial servant, Hans Leo Hassler.

However, there are more journey expenses in the Imperial ledgers, even if in other accounting section. A very interesting one is included in Gnadengeld (grace money), is dated 1577, and it documents a forthcoming journey of, in that time young trumpeter, Lucas Zigotta to Italy: ${ }^{25}$ we can imagine that he hasn't brought back to the Imperial court only music and instruments but also has contacted new Italian trumpet players which moved afterwards, in April 1578, from Udine to Prague: Francesco Sagabria,

20, ,...] auf sein unterthenigist supplicirn, weil Er viel lange Jar heer vleisig gedient, vom Ersten tag Januarij dits [...] Jars und hinfuro Jarlich fünfzig gulden reinisch zur einer Pension, und wann gedachten Cappa mit Todt abgeet, zur handen seiner haußfrauen Catharina Cappin solang die beyleben ist [...]“, ÖstA - HKA, HZAB 1587, Provision, f. 52v.

21 During the Rudolf's reign provisions were given to the widows of singers Daniel de Motta, Wilhelm de La Fontaine, Sigismund Rißer, Hans de Beckher, Auigio Fenice, Wilhelm Haan, Michael Prost / Proßman and those of trumpeters Leonso Cappa, Florindo Sertorio and Paul Zigotta.

22 ÖstA - HKA, HZAB 1591, Zehrung und Verehrung, f. 360r-361r. For further information on Rudolf's interest in new first-class musicians from the former Chapel of Charles II, Archduke of Austria see FEDERHOFER, Hellmut. Musikpflege und Musiker am grazer Habsburgerhof der Erzherzöge Karl und Ferdinand von Österreich (15641619). Mainz: B. Schott's Söhne, 1967, here p. 50, 99-100.

23 ÔstA - HKA, HZAB 1602, Zehrung, f. 417v-418r.

24 The Zehrung record in the volume of 1609 attests three Hassler's journeys from Ulm to Prague in 1605 , 1606 and 1607. Hassler, in fact, is called in some list of court personnel as non-resident servant (von haußaus).

25 ÓstA - HKA, HZAB 1577, Gnadengeld, f. 659v. 
Florindo Sertorio, Andrea Mosto and especially Alessandro Orologio, who became the vice chapel master after the death of Philipp de Monte in 1603. ${ }^{26}$

\section{Gnadengeld ("grace money")}

The last category of each Rudolfine accounting volume is the "grace money". It is quite large section and payment items in it are cumulative, more different payments together in an unique accounting record. The items are not structured, as in the rest of book, by name. Therefore, it will require a complete, separate and accurate study of entire category to extract payments on music. This category is very important from our point of view, since it documents numerous payments to those musicians who dedicated some composition to the Emperor (prints and manuscripts) ${ }^{27}$ and attest a wide scale of aspects regarding the musical life at the Emperor's court. For instance, it testify the presence in Prague of musicians who wanted to entry at the Imperial service but for some reason they haven't concluded. ${ }^{28}$

We have already mentioned the arrival of Francesco Mosto to the Imperial court from Graz in 1590. Since he died shortly after his coming to Prague and his name is never mentioned among regular wages, the only direct evidence that Francesco actually entered the Imperial service is the Gnadengeld record of an exceptional payment to bereaved widow. ${ }^{29}$

\section{A. 2 Sources in Austrian State Archives, Finanz- und Hofkammerarchiv: Other sources}

The Rudolfine accounting ledgers are completed in the Aulic Chamber Archive by Gedenkbücher and Hoffinanz volumes. These three typologies are all together an effective research instrument for historians. Their systematic comparison could bring quite a complete picture of the economical and social structures of the Rudolfine court, not only from the musical point of view.

Extremely rich in terms of additional data are the Niederösterreichische Herrschaftsakten. The collection includes numerous official musicians' requests of remunerations and

26 ŽÁČKOVÁ ROSSI, Michaela. Da Udine a Praga. La crescente fortuna dei musicisti alla corte imperiale di Rodolfo II. In Alessandro Orologio (1551-1633) musico friulano e il suo tempo. Atti del convegno internazionale di studi. (ed. Franco Colussi), Pordenone: Pizzicato, 2008, p. 265-276 and in the same conference proceedings, above all, COLUSSI, Franco. Scheda biografica di Alessandro Orologio e alcuni documenti inediti, p. 79-90.

27 ÖstA - HKA, HZAB 1587, Gnadengeld, f. 268v: the item attests a payment to Alessandro Orologio for his dedication of Il primo libro de' madrigali a cinque voci to the Emperor Rudolf II.

28 ÖstA - HKA, HZAB 1592, Gnadengeld, f. 560v: in 1592 the aulic chamber paid $116 \mathrm{fl.} 40 \mathrm{kr}$. (= 100 Taler, Dollars) to the Italian composer Tiburtio Massaino, probably for a music dedication. We can suppose that Massaino tried in some way to enter the service of the Emperor Rudolf II.

29 ÖstA - HKA, HZAB 1591, Gnadengeld, f. 416v: "Item Irer Mt: gewestes Musici unnd Zingenblasers Francisco Mosto wittib [...]". Morever, in August 1591, Francesco's son Marc'Antonio who was about fourteen years old was accepted into the Imperial service as a trumpet player apprentice, ÖstA - HKA, HZAB 1591, Unterhaltung Lehrjungen, f. 294v-295r, - see also notarial deed written up after Francesco Mosto's sudden death in the study LUNELLI, Clemente. Notizie di alcuni musicisti a Praga nel Cinquecento, Atti degli anni accademici 220-223 (Atti dell'Accademia Roveretana degli Agiati), series VI, fasc. X-XIII, f, A, 1970-1973, p. 137-142, here p. 139. 
bonuses, bringing light into the private life of Rudolfine musicians: Mateo Flecha, Martin Hastal, Wilhelm Formellis, Hieronymus De Leon, Andrea Mosto, Cesare Bendinelli, Jacob and Hans Leo Hassler, Paris Bergamino, Bonaventura Le Febure, Paul van Winde, Liberale Zanchi, Jacob Cuper, Lucas Zigotta but also Jacob Chimarrhaeus and Philipp de Monte presented their supplications for a contribution of various types. ${ }^{30}$ We can suppose that some of the requests, at least some of those for marriage and child's baptism, correspond with later Verehrung payments in the accounting books.

\section{A. 3 Sources in Austrian State Archives, Allgemeines Verwaltungsarchiv: ${ }^{31}$ Applications for coat-of-arms}

To the end of their Imperial service numerous musicians applied for a coat-of-arms or, generally, a kind of nobilitation, as we can see from the Frank's list of this kind of sources conserved in Austrian Archives. This is the case also of "Musici und Trometter" Cesare Bendinelli, Hans Drexl and Dominico Cappa before their departure to the court of Bavaria in 1582 or of Protasio and Zuanjusepo Celotti, other trumpeters who left the court in 1592 to return in the native Udine. The applications for coat-of arms were paid by the applicants themselves with a kind of administrative payment. ${ }^{32}$ They are very useful in terms of biographical data, they indicate frequently the family provenience and define other relatives in the Habsburg service.

Thus, it will be interesting now, when we have extracted from the Imperial accounting books the exact dates of the end of service for many of the Rudolfine musicians, to link the year of the end of service to the year of the request or according of the coat-of-arms.

\section{A.4 Sources in Austrian State Archives, Haus-, Hof- und Staatsarchiv: ${ }^{33}$}

Other important sources essential for the Rudolfine research are preserved in the Haus-, Hof- und Staatsarchiv. Robert Lindell was interested in so called Testimonium. "Such documents were created when someone left court service and served as a recommendation

30 ŐstA - HKA, NÖHA W 61 A 32 A.

31 ÖstA - AVA: the applications for coat-of-arms are preserved under the signature which is signed as „name + year of nobilitation" - an essential instrument for the research about nobilitation is FRANK, K. F. von. Standeserhebungen und Gnadenakte für das Deutsche Reich und die Österreichischen Erblande bis 1806 sowie kaiserlich österreichische bis 1823 mit einigen Nachträgen zum „Alt-Österreichischen Adels-Lexikon“ 1823-1918. 5 Bd. Schloss Senftenegg: Selbstverlag, 1967-1974.

32 MARGREITER, Klaus. Briefe an den Kaiser. Anträge auf Nobilitierung als Quelle für die mitteleuropäische Sozialgeschichte des 17. und 18. Jahrhunderts. In Reading, Interpreting and Historicizing. Letters as Historical Sources (ed. R. Schulte - X. von Tippelskirch). Badia Fiesolana: European University Institute, 2004, p. 123-134.

33 Österreichisches Staatsarchiv, Haus-, Hof- und Staatsarchiv [Austrian State Archives, Vienna, House of Habsburg, Aulic and State Archive] (hereafter ÖstA - HHStA) 
to new employers".34 At the conclusion of the musicians' service at the Habsburg Court, the official account ledgers recorded only that they had left "with grace" ("mit Gnaden verlassen”). We just talked about application for coat-of-arms which were sometime requested by the servants before the departure for another employment.

The so called Panis Briefe are other documents on the service conclusion, in particular on the last years of old servants when they applied for an assistance in some monastery. They should be studied in their entirety to understand better the social conditions of ancient servants. ${ }^{35}$ Besides, the Panis Briefe applications present autograph signatures of Rudolf's singers as Christian Hug, Georg Khnes, Michel Bayr, trumpeter Anthon Anthonino, Georg Kötterle and even, as for recommendation, of the chapel master Philipp de Monte, of the vice chapel master Alessandro Orologio and chief trumpeter Dominico Gentili. ${ }^{36}$

Finally, the collection of Privilegium Impressorum is a needful instrument for everybody who focuses on European musical prints of the late Renaissance and recently was elaborated by Hans-Joachim Koppitz. ${ }^{37}$

The Haus-, Hof- und Staatsarchiv offers many and many other significant testimonials on most of the Rudolfine musicians, as attested by the recent discovery of two Georg Zigotta's letters in Langakten, in the collection of the Emperor's chamber servant Philip Lang. ${ }^{38}$

\section{B. Sources in Wiener Stadt- und Landesarchiv: Testaments}

There is an important collection of testaments ${ }^{39}$ in the Wiener Stadt- und Landesarchiv, ${ }^{40}$ rich of additional biographical and social data they can provide us regarding the musicians, identification of their family members, who were often also musicians and, finally, some more news about the conditions they lived.

In 1992 Pavle Merku reported for the first time on the large testament of Rudolfine vice chapel master and well known composer Alessandro Orologio. ${ }^{41}$ In his study Merku included a transcription and the facsimile of this significant document, dated $27^{\text {th }}$ of

34 In 2008 Robert Lindell published his paper on the Testimonium for Alessandro Orologio - see LINDELL, Robert. Alessandro Orologio - chamber musician and vice chapelmaster of Emperor Rudolph II. In Alessandro Orologio (1551-1633) musico friulano e il suo tempo. Atti del convegno internazionale di studi. (ed. Franco Colussi), Pordenone: Pizzicato, 2008, p. 277-283.

35 HIRSCHMANN, Hans Jörg. Vom kaiserlichen Recht der Panis-Briefe. Jur. Diss. Marburg, 1973.

36 ÖstA - HHStA, Reichsakten in Specie, no. 64, 65a and 65b.

37 KOPPITZ, Hans-Joachim. Die kaiserlichen Druckprivilegien im Haus-, Hof- und Staatsarchiv Wien Verzeichnis der Akten vom Anfang des 16. Jahrhunderts bis zum Ende des Deutschen Reichs (1806). Wiesbaden: Harrassowitz Verlag, 2008.

38 In 2017 will be published, by author of this paper, a summary study about the interesting trumpeters family Zigotta, in particular about Jacob Zigotta and his sons Lucas, Paul and Georg.

39 Wiener Stadt- und Landesarchiv [Municipal and Provincial Archives of Vienna] (hereafter WSLA).

40 A testaments' inventory conserved in the WSLA, edited by Gugitz, is available for the researches directly in the archive's reading room.

41 WSLA, Alte Ziviljustiz - A1 - Testamente 4870. 
February $1633 .{ }^{42}$ To the Orologio's testament are related numerous, so far unpublished, Prague documents, as lists of unpaid Court salaries, letters or requests which give insight into the sad reality when ageing musicians and later their heirs repeatedly exact (often without success) unpaid wages, even in the $1630 \mathrm{~s}$ and until the $1660 \mathrm{~s} .{ }^{43}$ On the one hand side the Orologio's testament in Vienna and on the other hand side sources in Prague archives, documenting this hopeless situation of the heirs who after 20-30 years after the death of the composer still haven't seen part or nothing of the money indicated in the last will. ${ }^{44}$

In the Municipal and Provincial Archives are preserved further testaments, those of the Imperial singers Sebastian Röckhl ${ }^{45}$ and Nicolaus Busi, ${ }^{46}$ together with an extremely interesting will of the Rudolfine cammer musicus Giovanni Paolo Ardesi. ${ }^{47}$ This document, dated $1^{\text {st }}$ of October 1612, contributes to our knowledge about the Italian community in Prague, confirming St. Thomas Church in Lesser Town (Malá Strana) as another Italians' headquarters in Prague. In fact, Ardesi suggested to be buried - in the case he would die in Prague - in the "Italian Chapel" of the St. Thomas Church, next to his sister in law, Marta Sinibaldi, in the family grave: ${ }^{48}$ "[...] Se dio piace ch'io mora in praga sia sepulto in santo tomaso, nella capela italiana, dove sepulta la bona anima de mia cognata Marta, nella nostra sepoltura [...]." This is a very rare evidence about both the existence of

42 MERKŮ, Pavle. Alessandro Orologio in njegova oporoka / Alessandro Orologio und sein Testament. In Gallus Carniolus in europska renesansa / Gallus Carniolus und die europäische Renaissance. Ljubljana: Slovenska akademija znanosti in umetnosti, 1992, p. 171-184 and MERKŮ, Pavle. Il testamento di Alessandro Orologio. In Alessandro Orologio (1551-1633) musico friulano e il suo tempo. Atti del convegno internazionale di studi. (ed. COLUSSI, Franco), Pordenone: Pizzicato, 2008, p. 119-123.

43 These heir's requests and other documents regarding generally Rudolfine unpaid wages are preserved in Prague, in the Národní Archiv [National Archives] (hereafter NAČR), Stará manipulace S20 and S21 - for a preliminary information on musicisians present in the Stará manipulace is available for researchers an old paper cards catalogue with useful excerpts, preserved in Moravské Zemské Muzeum [Moravian Museum, Brno] - I would like to thank prof. Jiři Sehnal for his kind information about these regesta cards and the museum's staff for their precious assistance.

44 This was quite common situation, since at the beginning of 1612, thus the year of Rudolf's death, many musicians received their wages only up to the years 1606-1607 (whereas in 1576 when, Rudolf's father, Emperor Maximilian II died, contemporary payments were in the framework of 1574-1576 and were therefore paid out in maximum two-year delay). Many other musicians and sometimes their heirs presented in 20' and $30^{\prime}$ - even without a direct relation to a testament - unpaid wages during the reign of Rudolf II. The chamber musicians Marc'Antonio Mosto and Philipp Schoendorf's are the most prominent protagonists among these.

45 WSLA, Alte Ziviljustiz - A1 - Testamente 17563 (dated 1589).

46 WSLA, Alte Ziviljustiz - A1 - Testamente 2435 (dated 1608).

47 WSLA, Alte Ziviljustiz - A1 - Testamente 2428 (dated 1612).

48 The female singer Marta Ordelwring was the wife of the chamber musician, Mauro Sinibaldi and after his death in 1591 she married another chamber musician and important Imperial servant Carlo Ardesi, both ot them violinists from Cremona - on Marta focused his attention LINDELL, Robert. Marta gentil che '1 cor m'ha morto - Eine unbekannte Kammermusikerin am Hof Maximilians II. Musicologica Austriaca, 1987, no. 7, p. 59-68; LINDELL, Robert. Fillipo, Stephano and Martha: New Findings on Chamber Music at the Imperial Court in the Second Half of the 16th Century. In Atti del XIV Congresso della Società Internazionale di Musicologia. Trasmissione e recenzione della forme di cultura musicale. III. Free Papers. Torino: EDT, 1990, p. 869-875. See also LUNELLI, Clemente. Notizie di alcuni musicisti a Praga nel Cinquecento, Atti degli anni accademici 220-223 (Atti dell'Accademia Roveretana degli Agiati), series VI, fasc. X-XIII, f, A, 1970-1973, p. 137-142. 
an Italian Chapel in St. Thomas Church and in particular about the burial place of the Imperial singer Marta Sinibaldi.

In this study we have focused only on some of the most important sources preserved in Vienna archives. Besides, many unknown documents are still waiting for their discovering in other Austrian archives, in particular in Graz and Innsbruck but in archives and collections of local noble families and monasteries as well. ${ }^{49}$

Equally rich and full of surprises are Czech Republic archives. We have mentioned Prague sources only briefly, in the relation to Orologio's testament, since they are not the topic of this paper. Obviously, many other known non-musical archival sources are to be studied or even new relevant documents can be still discovered. Documents which attest the Prague Old Town, Lesser Town or Hradčany (castle) citizenship to the foreign musicians, documents about their houses acquisition or other extra-court businesses, books of debts, registers of births or deaths, testaments, lists of religious sodalities or confraternities are still to be placed in the context of the Prague Rudolfine environment. ${ }^{50}$

Further documents are in the Czech and Moravian provincial archives. They allow us to understand more about the relationships between local aristocracy and Emperor Rudolf's musicians. Such connections were not only musical, often we read about very practical services. ${ }^{51}$ Moreover, recent studies of Vladimír Maňas on the music at the court of Karl von Liechtenstein, and in particular on the composer Nicolas Zangius, have brought light on unknown archival sources related to the Rudolfine musical culture, demonstrating how important for our research on Imperial Habsburg environment also archives in Brno, Olomouc and Moravian monasteries can be. Finally, archives and libraries in the northern and central Italy remain, regarding the Rudolfine musical and especially non-musical sources, relatively unexplored.

The Rudolfine musical research started to be systematic already in 1980s thanks to the monograph of Carmelo Peter Comberiati, numerous studies of Robert Lindell and

49 In 2008 Alessandro Catalano published his study on the important find of the correspondence between Alessandro Orologio and Georg Sigmund von Lamberg, with a complete transcription of all thirty letters discovered in Oberösterreichisches Landesarchiv [Upper Austrian Archives] Linz, HA Steyr, FA Lamberg see CATALANO, Alessandro. Dai fasti musicali alla »benedetta podagra«. La corrispondenza tra Alessandro Orologio e Georg Sigmund von Lamberg. In Alessandro Orologio (1551-1633) musico friulano e il suo tempo. Atti del convegno internazionale di studi. (ed. Franco Colussi), Pordenone: Pizzicato, 2008, p. 91-117.

50 BAŤA, Jan. Jezuité a hudební kultura předbělohorské Prahy: Glosy ke vzájemné interakci na přŕkladu klementinské mariánské sodality. Bohemica Jesuitica 1556-2006. Prague: Karolinum, 2010, p. 1003-1009. The complete source edition is in press - KROUPA, Jiří K. (ed.). Pamětni kniha kongregace bl. Panny Marie při jezuitské koleji u sv. Klimenta v Praze (1575-1621).

51 For instance, the chief trumpeter Lucas Zigotta was in touch with Rosenberg family, not only for teaching of their young trumpet apprentices but also to provide wine for their court, as we can deduce from the Rožmberk (Rosenberg) accounting ledgers preserved in Státní oblastní archiv v Třeboni [State Regional Archives in Třeboň], CR 23 Rožmberkové. The same accounting records mention other Imperial musicians for their services (among these Franciscus Sale). Lucas Zigotta's brother, the trumpet player Georg, on the other hand, is documented in Žerotín's correspondence - see HRUBÝ, František. Ladislav Velen ze Žerotína. Praha: Historický klub v Praze, 1930, p. 43. 
especially to the fruitful activity of Petr Daněk ${ }^{52}$ and his students which provided the most wide-ranging overview on the topic of music in the Rudolfine environment. On this solid base an extraordinary international collaboration between musicologists of various provenance is allowing, in the last few years, an increased knowledge about relevant sources in different countries of the former Habsburg monarchy and in other European countries. $^{53}$

\section{Bibliography (selected titles):}

COLUSSI, Franco (ed.). Alessandro Orologio (1551-1633) musico friulano e il suo tempo. Atti del convegno internazionale di studi. Pordenone: Pizzicato, 2008.

COMBERIATI, Carmelo Peter. Late Renaissance Music at the Habsburg Court. Polyphonic Settings of the Mass Ordinary at the Court of Rudolf II (1576-1612). New York: Gordon and Breach, 1987.

DANĚK, Petr. Auswahlbibliographie zur Musikkultur am Hof Rudolfs II. Studia Rudolphina, 2009, no. 9 , p. $142-155$.

EVANS, Robert John Weston. Rudolf II and his World. A study in intellectual history, 1576-1612. Oxford: Clarendon Press, 1973.

FEDERHOFER, Hellmut. Musikpflege und Musiker am grazer Habsburgerhof der Erzherzöge Karl und Ferdinand von Österreich (1564-1619). Mainz: B. Schott's Söhne, 1967.

FRANK, K. F. von. Standeserhebungen und Gnadenakte für das Deutsche Reich und die Österreichischen Erblande bis 1806 sowie kaiserlich österreichische bis 1823 mit einigen Nachträgen zum „Alt-Österreichischen Adels-Lexikon“ 1823-1918. 5 Bd. Schloss Senftenegg: Selbstverlag, 1967-1974.

HAUSENBLASOVÁ, Jaroslava. Der Hof Kaiser Rudolfs II. Eine Edition der Hofstaatsverzeichnisse 1576-1612. Prag: Artefactum, 2002.

HENGERER, Mark. Die Abrechnungsbücher des Hofzahlmeisters (1542-1714) und die Zahlamtsbücher (1542-1825) im Wiener Hofkammerarchiv. In Quellenkunde der Habsburgermonarchie (16.-18. Jahrhundert). Ein exemplarisches Handbuch. Wien - München: R. Oldenbourg Verlag, 2004, p. 128-143.

LINDELL, Robert. Hudební život na dvoře Rudolfa II. Hudebni věda, 1989, no. 2, p. 99-111.

LINDELL, Robert. Music at the Court of Rudolf II. In Gallus Carniolus in evropska renesansa II. / Gallus Carniolus und die europäische Renaissance II. Ljubljana: Slovenska akademija znanosti in umetnosti, 1992, p. 155-169.

52 For the related bibliography see DANĚK, Petr. Auswahlbibliographie zur Musikkultur am Hof Rudolfs II. Studia Rudolphina, 2009, no. 9, p. 142-155.

53 Profesional musicologists and students interested in study of music and musical culture associated with the court of Emperor Rudolf II, working at their home institutions in various countries, both within and outside Europe. Their collaboration within Musica Rudolphina consists mainly in exchange of information, consultation concerning the manner of its publication, and coordination of research topics. The Musica Rudolphina members are Jan Bała, Petr Daněk, Scott Lee Edwards, Ferran Escrivà-Llorca, Klemen Grabnar, Markus Grassl, Erika Supria Honisch, Martin Horyna, Marta Hulková, Gabor Kiss, Jiří K. Kroupa, Vladimír Maňas, Stanislav Tuksar and Michaela Žáčková Rossi. On the official website of Musica Rudolphina, other information and an extensive Rudolfine musical bibliography can be found - http://www.bibemus.org/musicarudolphina/index_en.html. 
LINDELL, Robert. Music and patronage at the court of Rudolf II. In Music in the German Renaissance. John Kmetz (ed.). Cambridge: Cambridge University Press, 1994, p. 254-271.

LUNELLI, Clemente. Notizie di alcuni musicisti a Praga nel Cinquecento, Atti degli anni accademici 220-223 (Atti dell'Accademia Roveretana degli Agiati), series VI, fasc. X-XIII, f, A, 1970-1973, p. $137-142$.

MARGREITER, Klaus. Briefe an den Kaiser. Anträge auf Nobilitierung als Quelle für die mitteleuropäische Sozialgeschichte des 17. und 18. Jahrhunderts. In Reading, Interpreting and Historicizing. Letters as Historical Sources. Badia Fiesolana: European University Institute, 2004, p. $123-134$.

MERKU, Pavle. Alessandro Orologio in njegova oporoka / Alessandro Orologio und sein Testament. In Gallus Carniolus in evropska renesansa II. / Gallus Carniolus und die europäische Renaissance II. Ljubljana: Slovenska akademija znanosti in umetnosti, 1992, p. 171-184.

PÁNEK, Jaroslav. Knihy habsburské Dvorské pokladny (Hofzahlamtsbücher) jako pramen k dějinám předbělohorského českého státu. In Pocta prof. JUDr. Karlu Malému, DrSc. $k$ 65. narozeninám. Ladislav Soukup (ed.). Praha: Karolinum, 1995, p. 173-181.

PASS, Walter. Musik und Musiker am Hof Maximilians II. Tutzing: Hans Schneider, 1980.

PAUSER, Josef - SCHEUTZ, Martin - WINKELBAUER, Thomas (eds.). Quellenkunde der Habsburgermonarchie (16.-18. Jahrhundert). Ein exemplarisches Handbuch. Wien - München: R. Oldenbourg Verlag, 2004.

RIETSTAP, J. Armorial général, contenant la description des armoiries des familles nobles et patriciennes de l'Europe, précédé d'un dictionnaire des termes du blason. Gouda: G. B. van Goor, 1861.

SAPPER, Christian. Die Zahlamtsbücher im Hofkammerarchiv 1542-1825. Mitteilungen des Österreichischen Staatsarchivs, 1982, no. 35, p. 404-455.

SMIJERS, Albert. Die kaiserliche Hofmusikkapelle von 1543-1619. Studien zur Musikwissenschaft 1919, no. VI, p. 139-186; 1920, no. VII, p. 102-142; 1921, no. VIII, p. 176-206; 1922, no. IX, p. $43-81$.

ŽÁČKOVÁ ROSSI, Michaela. The Musicians at the Court of Rudolf II (1576-1612). Die Tonkunst, 2012, no. 3, p. 330-339. 
